\title{
PENGARUH KOMUNIKASI ORGANISASI TERHADAP EFEKTIVITAS KINERJA PEGAWAI DI PUSAT PENGEMBANGAN SUMBER DAYA MANUSIA APARATUR (PPSDMA)
}

\author{
Dian Anggarini \\ Pusat Pengembangan Sumber Daya Manusia Aparatur \\ dian.anggarini@esdm.go.id
}

\begin{abstract}
ABSTRAK
Pusat Pengembangan Sumber Daya Manusia Aparatur (PPSDMA) sebagai oganisasi yang memberikan jasa pelayanan pengembangan pegawai di lingkungan KESDM melalui pendidikan dan pelatihan, maka penyebarluasan serta penerimaan informasi secara efektif akan berpengaruh pada kinerja pegawai untuk mencapai tujuan bersama di unit PPSDMA. Tujuan penelitian ini adalah untuk mengetahui pengaruh komunikasi organisasi yang diterapkan oleh PPSDMA terhadap efektivitas kinerja pegawai. Metode penelitian bersifat deskriptif kuantitatif dengan skala yang digunakan ialah skala likert dengan teknik penyebaran data primer (kuesioner) pendekatan analisis SPSS. Populasi dalam penelitian ini ada 76 pegawai dan yang menjadi sampel sebanyak 47 pegawai. Analisis hasil penelitian ini menunjukkan bahwa terdapat korelasi positif yang signifikan antara pengaruh komunikasi organisasi dengan efektivitas kinerja pegawai ditandai dengan adanya nilai $\mathrm{r}$ sebesar 0.641 yang berarti besarnya pengaruh komunikasi organisasi terhadap efektivitas kinerja pegawai adalah sebesar $41 \%$, sedangkan sisanya yakni sebesar $59 \%$ diterangkan oleh variabel lain yang tidak diteliti.
\end{abstract}

Kata Kunci: Komunikasi organisasi, Efektivitas Kinerja

\begin{abstract}
Human Resource Development Centre for Government Apparatus is an organization that provides human development services at the Ministry of Energy and Mineral Resources through training and education, so effective disseminations will influence employees' performance to achieve the organizational vision. The purpose of this research was to find out the effect of organizational communication that has been implemented towards the effectiveness of employee performance. The research method was a quantitative description using Likert scale through primary data dissemination techniques approach (SPPS). The numbers of employees are 76 employees, but the respondents were only 47 employees. The result of this research indicates that there was a significant correlation between organizational communicating influence and the effectiveness of employee performance marked with $R$-value 0.641. It meant the magnitude of organizational communicating influence towards the effectiveness of employee performance was approximately $41 \%$, while the remaining result was around $59 \%$ that was explained by other variables.
\end{abstract}

Keywords: organizational communication, performance effectiveness

\section{PENDAHULUAN}

\section{Latar Belakang}

Komunikasi sangat berperan penting dalam kehidupan individual ataupun di dalam sebuah organisasi. Harold D Lasswell mengemukakan bahwa fungsi organisasi antara lain: (1) manusia dapat mengontrol lingkungannya, (2) beradaptasi dengan lingkungan tempat mereka berada, serta (3) melakukan transformasi warisan sosial kepada generasi berikutnya (Cangara 2007:59). Melalui komunikasi, manusia dapat dengan cepat mencari teman, mudah memelihara hubungan baik antara rekan kerja juga antara staf dan pimpinan.
Sebuah organisasi merupakan sesuatu yang berupa fisik dan nyata, serta memiliki struktur dengan batasan yang jelas. Istilah organisasi menggambarkan sesuatu yang konkret yang terdiri dari sumber daya manusia, interaksi dan transaksi dengan tujuan-tujuan sehingga organisasi terlihat sebagai tempat atau wadah yang terbentuk akibat dari perilaku individu yang menunjukkan pesan baik secara verbal dan non-verbal yang dilakukan secara terus menerus. Cara manusia sebagai pemroses informasi, menguraikan dan menafsirkan pesan mempunyai pengaruh besar pada kinerja dari organisasi. Kemampuan organisasi dalam 
menghadapi era modern tergantung pada kemampuan memobilisasi sumber daya manusia, karena kekuatan suatu organisasi terletak pada manusianya, bukan pada sistemnya, teknologinya, prosedurnya atau sumber dananya (Uchana, 1988:57). Oleh karena itu, komunikasi organisasi lebih dari sekedar alat, melainkan adalah cara berpikir bagi seluruh pimpinan dan karyawan sebagai anggota organisasi dalam peningkatan kinerja pegawai demi tercapainya visi, misi dan nilai yang telah ditetapkan oleh organisasi.

Pusat Pengembangan Sumber daya Manusia Aparatur (PPSDMA), memiliki tugas melaksanakan pengembangan sumber daya manusia aparatur di lingkungan Kementerian Energi dan Sumber Daya Mineral (KESDM), khususnya di bidang kepemimpinan, manajemen, dan administrasi. Sebagai organisasi yang memberikan jasa pelayanan pengembangan pegawai di lingkungan KESDM melalui pendidikan dan pelatihan, maka penyebarluasan serta penerimaan informasi secara efektif akan berpengaruh pada kinerja pegawai di unit PPSDMA dalam memberikan pelayanan dimulai dari hubungan komunikasi, motivasi, pembinaan, pemecahan masalah, pengambilan keputusan, dan kepuasan pelanggan merupakan komponen penting yang akan menjadi cerminan penilaian terhadap brand organisasi tersebut, tetapi dalam menjalankan komunikasi dalam organisasi yang efektif pada PPSDMA kadangkala ditemui kendala diduga seperti perbedaan informasi dalam penerimaan pesan.

Kurang terciptanya kesamaan makna, kurang terjadinya hubungan yang interaktif berdasarkan kendala-kendala tersebut maka penulis meneliti dengan judul Pengaruh Efektivitas Komunikasi Organisasi Terhadap Efektivitas Kinerja Pegawai di Lingkungan PPSDMA ini dilakukan penelitian yang bersifat deskriptif untuk menjawab rumusan masalah dengan menggunakan pendekatan kuantitatif, yang dipergunakan supaya memperoleh informasi luas namun tidak mendalam. Untuk memperjelas hasil penelitian ini, menggunakan analisa data primer.

\section{Perumusan Masalah}

Berdasarkan latar belakang permasalahan yang dikemukakan sebelumnya maka peneliti menarik rumusan masalah sebagai berikut:

"Bagaimana pengaruh efektivitas komunikasi organisasi yang diterapkan oleh PPSDM Aparatur terhadap efektivitas kinerja para pegawainya?"

\section{TINJAUANTEORI}

\section{Komunikasi Organisasi}

Di dalam sebuah organisasi, komunikasi dapat diibaratkan sebagai aliran darah di tubuh. Alur komunikasilah yang menyampaikan perintah dari pimpinan ke staf, mengantarkan laporan dari staf kepada pimpinan; atau menginformasikan pesan antarpimpinan atau antarstaf sehingga membuat organisasi mampu mencapai tujuannya. Apabila komunikasi dalam suatu organisasi tidak berjalan, maka organisasipun berhenti beroperasi. Memperbaiki komunikasi organisasi berarti memperbaiki hal-hal untuk mencapai tujuan organisasi.

\section{a. Definisi Komunikasi Organisasi}

Komunikasi organisasi adalah pengiriman dan penerimaan informasi komunikasi dalam organisasi yang kompleks, dimana hal tersebut berkenaan dengan komunikasi internal, hubungan manusia, hubungan persatu pengelola, komunikasi downward atau komunikasi dari atasan kepada bawahan, komunikasi upward atau komunikasi dari bawahan kepada atasan, komunikasi horizontal atau komunikasi dari orang-orang yang sama level/tingkatnya dalam organisasi, keterampilan berkomunikasi dan berbicara, mendengarkan, menulis dan komunikasi evaluasi program (Muhammad, 2005:65).

Komunikasi organisasi juga dapat diartikan sebagai proses penciptaan dan pertukaran pesan dalam satu jaringan hubungan yang saling tergantung satu sama lain untuk mengatasi lingkungan yang tidak pasti atau yang selalu berubah-ubah (Rachmat Krisyantono, 2006).

Dari semua pembahasan yang telah dikemukakan di atas berkaitan dengan korelasi antara ilmu komunikasi dan organisasi terletak pada tinjauannya yang fokus pada manusia-manusia yang berada di organisasi untuk bekerjasama mencapai tujuan organisasinya, sehingga penulis dapat menyimpulkan bahwa komunikasi organisasi ialah hal yang paling mendasar dan sangat penting, karena apabila komunikasi organisasi tidak ada, maka informasi yang merupakan bagian dari organisasi tidak akan tersampaikan, dan karena komunikasi organisasi pula seluruh pegawai yang ada di unit organisasi dapat memahami dan menjalankan tujuan dari organisasi secara bersama-sama.

\section{b. Unsur-Unsur Komunikasi}

Harold Lasswell (Effendy, 2005: 10) dalam karyanya The Structure and Function of Communication In Society sering kali dikutip oleh para peminat komunikasi. Menurut Lasswell 
bahwa cara yang tepat untuk menjelaskan komunikasi adalah dengan menjawab pertanyaan sebagai berikut: who says what in which channel to whom what effect? Dalam paradigma tersebut menunjukkan bahwa ada lima unsur yang terdapat di dalam komunikasi, yaitu: (1). Penyampai Pesan (Komunikator): Komunikator merupakan seseorang yang memberikan pesan kepada komunikan, sehingga seorang komunikator harus mengetahui dan memahami hal yang akan disampaikan karena sebuah pesan tidak akan diterima dengan baik apabila komunikatornya tidak memahami hal yang disampaikannya; (2) Pesan: sebuah pesan yang disampaikan harus memiliki makna yang mudah dipahami dan dimengerti oleh komunikan; (3) Media: penyaluran sebuah pesan dapat digunakan berbagai macam media. Media yang digunakan antara lain televisi, radio, telepon, surat, koran, majalah, dan lain sebagainya; (4) Penerima Pesan (Komunikan): komunikator sebaiknya mengetahui kepada siapa akan disampaikan, karena komunikasi dikatakan berhasil apabila pesan tersebut diterima dan dipahami dengan baik oleh komunikan; dan (5) Efek: Pesan dikatakan memiliki arti bagi komunikan apabila pesan tersebut berdampak pada perubahan sudut pandang komunikan, misalnya cara berpikir, sikap, perilaku, dan lain-lain.

Setiap unsur dalam penyampaian pesan memiliki keterkaitan yang sangat erat dan saling berhubungan satu sama lain sehingga dapat menentukan keberhasilan dari sebuah komunikasi, baik dalam lingkup individu, masyarakat maupun komunikasi di dalam organisasi.

\section{c. Bentuk Dasar Komunikasi}

Cara berkomunikasi dapat mempengaruhi sampainya sebuah pesan yang diterima dan dimengerti dalam rangka meningkatkan aktivitas hubungan antar manusia atau organisasi. Dalam konteks ilmu komunikasi dijelaskan tentang dua bentuk komunikasi yang sering terjadi yaitu: (1) komunikasi verbal, dapat dikatakan sebagai bentuk komunikasi yang jelas dan tegas dengan mencakup aspek-aspek antara lain vocabulary (perbendaharaan kata), racing (kecepatan), intonasi suara, humor, singkat dan jelas,serta timing (waktu yang tepat); dan (2) komunikasi nonverbal adalah suatu penyampaian pesan yang terjadi secara samar-samar (tanpa kata-kata) tetapi dipahami sebagai bentuk komunikasi, antara lain: ekspresi wajah, kontak mata, sentuhan, postur tubuh dan gaya berjalan, sound (suara), serta gerak isyarat.

\section{d. Proses Komunikasi}

Salah satu tantangan terbesar dalam proses komunikasi adalah bagaimana informasi dan pesan yang disampaikan dapat diterima dengan jelas ke seluruh bidang dan bagian organisasi. Secara umum proses komunikasi dapat memberikan gambaran kepada pengelola organisasi tentang cara mempengaruhi atau mengubah sikap anggotanya melalui model implementasi. Dalam hal ini komunikator bisa saja merupakan individu ataupun berupa suatu organisasi sebagaimana dapat dilihat pada Gambar 1.

Dari apa yang tergambarkan pada gambar $1 \mathrm{di}$ bawah, suatu pesan sebelum disampaikan pertama-tama disandikan (encoding) ke dalam simbol-simbol yang menggambarkan pesan yang ingin disampaian oleh pengirim. Simbol apapun yang digunakan oleh pengirim, tujuannya adalah menyediakan pesan secara maksimal agar penerima pesan dapat memahami maksud dari pengirim secara tepat. Pesan yang dikirimkan

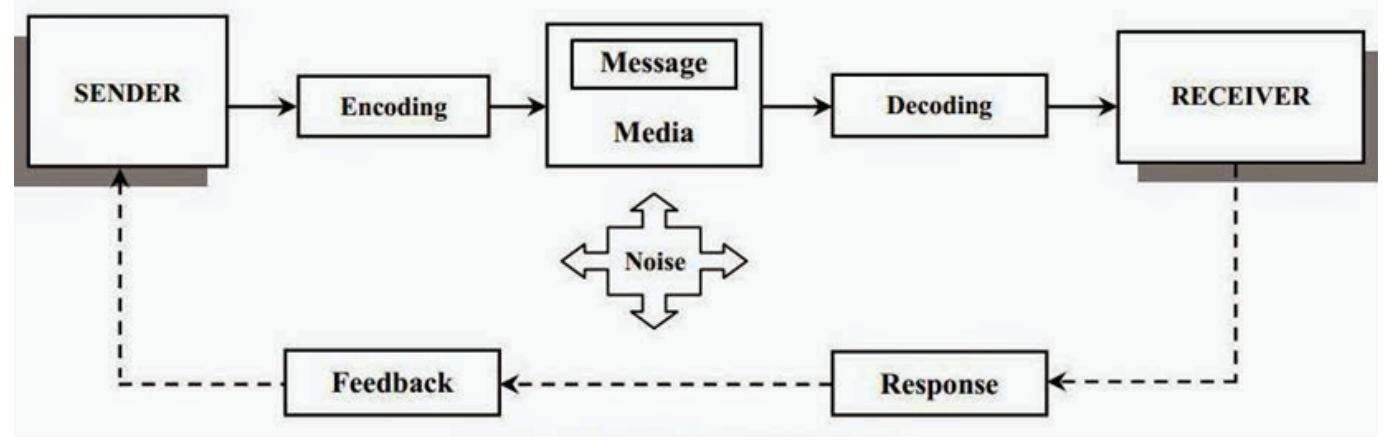

Gambar 1. Proses Komunikasi

Sumber:http://file.upi.edu/Direktori/FPEB/PRODI.MANAJEMEN

FPEB/197207152003121-CHAIRUL FURQON/Artikel-Organizational

Communication.pdf (20 November 2018) 
disalurkan melalui suatu media tertentu, yang selanjutnya akan ditransformasikan ulang (decoding) menjadi kata-kata/kalimat atau bahasa yang dipahami sehingga menjadi pesan yang sesuai dengan harapan (perceived message).

Hasil utama yang diharapkan dari proses komunikasi yaitu adanya perubahan perilaku penerima pesan sesuai dengan maksud dan tujuan pengirim pesan. Proses komunikasi dikatakan berjalan dua arah apabila adanya umpan balik, artinya adanya interaksi yang membuat pengirim bisa menjadi penerima juga sebaiknya. Interaksi yang terjadi memungkinkan terjadi proses saling memantau seberapa efektif pesan tersampaikan dan ditafsirkan dengan benar oleh penerima. Dalam proses komunikasi sering dimunculkan konsep kegaduhan (noise) untuk memlihatkan bahwa ada hambatan yang dapat terjadi di dalam proses komunikasi. Hambatan dapat terjadi pada pengirim, saluran/media, penerima pesan ataupun pada umpan balik. Artinya semua unsur dalam proses komunikasi memiliki potensi sebagai hambatan dalam proses komunikasi.

\section{e. Fungsi Komunikasi Dalam Organisasi}

Selayaknya seorang pemimpin sudah seharusnya dapat berkomunikasi dengan baik kepada pegawainya, sehingga komunikasi dapat berjalan sebagaimana fungsinya dan dapat berkontribusi secara riil terhadap tujuan dari organisasi.

Fungsi penting komunikasi organisasi menurut Brent D Ruben (Alo Liliweri: 2004: hal 64), yaitu:

1) Mengkoordinasikan aktivitas individu, kelompok atau unit-unit lain dalam organisasi.

2) Memberikan pengarahan organisasi secara keseluruhan.

3) Memfasilitasi pertukaran informasi dalam organisasi.

4) Menjamin adanya arus timbal balik (two way flow information) antara organisasi dan lingkungan eksternal (di luar) organisasi.

Para pembuat kebijakan perlu menilai seberapa baik struktur dan proses memfasilitasi komunikasi yang jelas dan terarah untuk mencapai tujuan organisasi serta memberikan umpan balik bagi peserta, dan memastikan bahwa peningkatan prestasi kerja yang diinginkan terpenuhi (Rajeswari Devadas: 2011).

\section{f. Aliran Informasi Dalam Organisasi}

Aliran informasi dalam suatu organisasi pada kenyataannya adalah suatu proses di mana pesanpesan secara dinamis terus berlangsung dan terjadi sepanjang waktu.

Dalam komunikasi organisasi, pesan mengalir melalui jalan resmi atau berbicara tentang informasi yang bergerak secara formal dengan alur pesan yaitu:

1) Seseorang dengan otoritas lebih tinggi kepada otoritas yang lebih rendah atau "downward communication", yang digunakan untuk menyampaikan informasi yang berkaitan dengan pengarahan, tujuan, tugas, perintah, pertanyaan, dan kebijakan yang umum. Ada lima jenis informasi yang biasanya dikomunikasikan dari atasan kepada bawahan (Katz \& Kahn, 1966): (1) informasi mengenai bagaimana melakukan pekerjaan, (2) informasi mengenai dasar pemikiran untuk melakukan pekerjaan, (3) informasi mengenai kebijakan dan praktik-praktik organisasi, (4) informasi mengenai kinerja pegawai, dan (5) informasi untuk mengembangkan rasa memiliki tugas (sense of mission).

2) Pesan yang bergerak dari jabatan lebih rendah kepada jabatan yang lebih tinggi/komunikasi ke atas atau "upward communication". Para pimpinan harus mendorong, merangsang, dan mencari metode yang tepat agar mengembangkan komunikasi ke atas. Dengan berjalannya komunikasi ini secara berkesinambungan, maka para pemimpin juga harus bersedia menerima informasi dari bawahan dan memberikan respons berupa tindakan untuk menanggapi informasi yang disampaikan agar organisasi berfungsi baik.

3) Pesan yang bergerak dilingkup yang sama otoritasnya/komunikasi horizontal atau "horizontal communication". Pengiriman pesan diantara rekan sejawat yang biasanya terkait dengan tugas pekerjaan seperti koordinasi, problem solving, penyelesaian konflik, dan saling berbagi informasi.

Komunikasi pimpinan yang baik dapat dikatakan sebagai ujung tombak dari komunikasi organisasi yang akan berjalan efektif dalam prosesnya dengan mencakup lima hal sebagai berikut: (1) adanya kemampuan komunikasi untuk menanamkan keyakinan; (2) adanya kemampuan komunikasi untuk memperoleh dukungan dari anggota untuk mencapai tujuan organisasi; (3) adanya komunikasi pimpinan untuk menghidupkan rasa percaya diri; (4) adanya komunikasi pimpinan untuk bertanya apa dan mengapa; dan (5) adanya komunikasi pimpinan dalam instruksi, penghargaan, dan sanksi. 


\section{Efektivitas Kinerja}

Organisasi jika ingin berkembang dan terus mencapai tujuannya haruslah memiliki pegawai yang kompeten atau berkualitas. Pegawai yang memiliki kualitas merupakan pegawai yang kinerjanya selalu mencapai target atau sasaran yang telah ditetapkan organisasi sesuai dengan tugas dan fungsinya dari pegawai tersebut.

\section{a. Definisi Kinerja}

Kinerja merupakan suatu tanda hasil pencapaian hasil tujuan organisasi yang di dalamnya termasuk hasil kegiatan individu atau kelompok baik secara kuantitas maupun kualitas. Hersey, Blanchard dan Johnson (1996) dalam Huber (2006) mengemukakan bahwa kinerja merupakan upaya untuk mencapai tujuan dan tanggungjawab organisasi. Kinerja adalah hasil akhir kegiatan atau prestasi yang dicapai seseorang dalam melaksanakan tugas atau prestasi yang dicapai seseorang dalam melaksanakan tugas atau pekerjaannya sesuai dengan standard an kriteria yang ditetapkan (Robbins \& Coulter, 2005/2007; Rivai, 2005).

Lebih dalam (Indra Bastian, 2001. Hlm. 329), menyatakan bahwa kinerja adalah gambaran mengenai tingkap pencapaian pelaksanaan suatu kegiatan/program/kebijaksanaan dalam mewujudkan sasaran, tujuan, visi dan misi organisasi yang tertuang dalam perumusan skema strategis (strategic planning) suatu organisasi. Terkait dengan PPSDMA sebagai organisasi pengembangan sumber daya manusia aparatur, kinerja pegawai dapat diartikan sebagai hasil dari kegiatan pegawai dalam melaksanakan capaian mengembangkan SDM aparatur di KESDM sesuai dengan tugas dan fungsinya.

\section{b. Definisi Efektivitas Kinerja}

Efektivitas (effectiveness) secara umum dapat diartikan "melakukan sesuatu yang tepat" (stoner, 1999). Menurut Ravianto dalam Masruri (2014:11) efektivitas merupakan seberapa baik pekerjaan dapat diselesaikan dengan adanya perencanaan, baik mengenai waktu, biaya dan juga mutu, maka dapat dikatakan efektif.

Berdasarkan beberapa definisi dapat disimpulkan bahwa efektivitas adalah capaian dari tujuan dalam lingkup organisasi yang terkait dengan pelaksanaan kegiatan yang harus didukung oleh sumber daya manusia (SDM) yang memiliki kemampuan, keahlian dan keterampilan sehingga memperoleh hasil sesuai dengan yang telah ditetapkan.

Efektivitas kinerja dapat dijabarkan sebagai suatu kemampuan untuk menentukan target yang tepat sesuai dengan tujuan yang telah ditetapkan. Efektivitas kinerja akan meningkat apabila seseorang memiliki keterampilan dan keahlian yang sesuai dengan kebutuhan dan tuntutan dari pekerjaan.sedangkan menurut Sondang P Siagian (1994) memberikan pandangan bahwa "efektivitas kerja berarti penyelesaian pekerjaan yang telah ditentukan dan dapat diselesaikan tepat pada waktunya.".

Dari definisi-definisi yang telah dijabarkan di atas, maka efektivitas kinerja dapat diterangkan sebagai kemampuan untuk melaksanakan kegiatan secara tepat yang berdasarkan pada tujuan yang telah disepakati atau ditetapkan, apabila muncul ketidaksesuaian pelaksanaan kegiatan dengan tujuan yang dimaksud oleh organisasi maka terlihat bahwa pelaksanaan kegiatan tersebut belum efektif.

\section{c. Faktor-Faktor Yang Mempengaruhi Efektivitas Kinerja}

Beberapa faktor yang mempengaruhi efektivitas kinerja, menurut Danim (2004) efektivitas kinerja dipengaruhi oleh interaksi antar - sesama yang menakup hal-hal berikut:

1) Gaya kepemimpinan, dapat mempengaruhi efektivitas kinerja diantaranya: otoriter, demokratis, pseudo demokratis, situasional, paternalistis, orientasi pemusatan, dan lain-lain.

2) Ketergantungan, dapat mempengaruhi efektivitas kinerja misalnya: ketergantungan penuh, ketergantungan sebagian, ketergantungan situasional, dan tidak adanya ketergantungan.

3) Hubungan persahabatan dapat mempengaruhi efektivitas kinerja, misalnya: kaku, longgar, situasional, berpusat pada seseorang dan berpusat secara kombinasi.

4) Kultur juga dapat mempengaruhi efektivitas kinerja seperti: menghambat atau menunjang.

5) Kemampuan adaptasi juga dapat mempengaruhi efektivitas, misalnya ada yang cepat dan ada yang lambat beradaptasi dengan lingkungannya, situasional dan ada yang tidak dapat berinteraksi.

6) Sistem nilai seseorang juga dapat mempengaruhi efektivitas misalnya: tipe terbuka, tertutup dan prasangka.

Kemampuan setiap individu dalam melaksanakan pekerjaannya sesuai dengan tujuan dan target yang telah ditetapkan menjadi salah satu indikator bahwa kinerja berjalan dengan efektif. Sedangkan kemampuan organisasi untuk mengelola setiap individu dapat bertanggungjawab dan menjamin konsistensi pada hasil menjadi kunci dalam peningkatan efektivitas kinerja. 


\section{d. Penilaian Kinerja}

Definisi penilaian kinerja menurut Andrew E Sikula yang dikutip oleh Anwar Prabu Mangkunegara dalam bukunya yang berjudul evaluasi Kinerja Sumber Daya Manusia (2005:10) adalah sebagai berikut: "Penilaian pegawai merupakan evaluasi yang sistematis dari pekerjaan pegawai dan potensi yang dapat dikembangkan. Penilaian adalah proses penaksiran atau penentuan nilai, kualitas atau status dari beberapa objek, orang atau perusahaan."

Penilaian kinerja merupakan suatu sarana dalam melakukan penilaian secara berkala terhadap kinerja pegawai yang mengacu pada system formal dan terstruktur sehingga mendukung tercapainya tujuan organisasi dengan proses penilaian berdasarkan perbandingan kinerja antar pegawai dalam melaksanakan jenis yugas yang sama.

\section{e. Evaluasi Kinerja}

Evaluasi kinerja merupakan alat bantu mengatasi persoalan organisasi yangberkaitan dengan akuntabilitas organisasi dalam menghasilkan pelayanan publik dengan melihat hasil perbandingan dari tujuan yang ingin dicapai dengan fakta. Menurut (Schulerr \& Jackson: 2006) menyatakan bahwa penilaian kinerja melibatkan evaluasi kinerja yang didasarkan pada penilaian dan pendapat dari para bawahan, rekan kerja, atarsan manajer lainnya dan bahkan karyawan itu sendiri.

\section{f. Indikator Kinerja}

Indikator kinerja adalah ukuran kuantitatif atau kualitatif yang menggambarkan tingkat pencapaian suatu sasaran atau tujuan yang telah ditetapkan (BPKP dalam Abdullah, 2014:145). Menurut Mahmudi (2015:91), informasi sangat penting dalam rangka meningkatkan good governance.

Dapat disimpulkan bahwa indikator kinerja merupakan alat bagi organisasi sektor publik untuk memberikan tanda-tanda bagi pihak internal untuk melakukan evaluasi dan pemantauan berbagai aspek aktivitas kinerja organisasi dan pihak eksternal untuk mengukur kinerja organisasi.

\section{Hipotesis Penelitian}

Komunikasi adalah salah satu komponen penting yang menunjukkan adanya kehidupan berdasarkan kerjasama yang sinergis dan harmonisasi antara pimpinan dan staf yang saling mendukung, sehingga komunikasi organisasi senatiasa dapat memperkokoh kinerja pegawai.
Dalam penelitian ini diperlukan hipotesis untuk menarik kesimpulan yang akan dibuktikan dan diteliti serta diuji kebenarannya. Dengan hipotesis sebagai berikut:

- Ha: terdapat hubungan positif yang signifikan dari komunikasi organisasi terhadap efektivitas kinerja pegawai PPSDMA.

- Ho: Tidak terdapat hubungan positif yang signifikan dari komunikasi organisasi terhadap efektivitas kinerja pegawai PPSDMA.

\section{METODE PENELITIAN}

Penelitian ini dilakukan di organisasi pemerintah di salah satu unit eselon dua (2) Kementerian Energi dan Sumber Daya Mineral (KESDM), yaitu di Pusat Pengembangan Sumber Daya Manusia Aparatur (PPSDMA), Jalan Cisitu lama Nomor 37, Dago - Coblong, Bandung. Penelitian ini menggunakan pendekatan kauntitatif untuk mengetahui pengaruh komunikasi organisasi terhadap efektivitas kinerja pegawai di PPSDMA.

Responden yang diambil adalah pegawai negeri sipil di PPSDMA, dengan responden yang mengisi kuesioner sejumlah empat puluh tujuh orang pegawai. Hal ini sudah memenuhi standar jumlah responden karena jumlah PNS di PPSDMA sejumlah tujuh puluh enam pegawai Aparatur Sipil negara (ASN).

Metode pengumpulan data dilakukan dengan menggunakan dua jenis data yang sangat dibutuhkan dalam penelitian ini, yaitu data primer dan data sekunder. Data primer ialah data yang didapatkan secara langsung dari responden berupa daftar pertanyaan yang diperoleh melalui kuesioner, sedangkan data sekunder ialah data yang telah dioleh, seperti buku, jurnal, artikel maupun pemberitaan.

Pengambilan data dilakukan dengan menyebarkan daftar pertanyaan yang harus diisi kepada selulruh pejabat fungsional, pejabat struktural dan pegawai, untuk mendapatkan masukan data yang lebih komprehensif. Hasil pengisian kuesioner oleh responden dikumpulkan mengenai data diri responden, yaitu jenis kelamin, usiam tingkat pendidikan, dan masa kerja yang menyangkut indikator variabel yang diteliti, kemudian dilakukan uji validitas dengan menggunakan SPSS (Statistical Packages for Social Science) for Windows 23..0.

Sampel adalah subset dari populasi, terdiri dari beberapa anggota populasi. Subset ini diambil karena banyak kasus yang tidak mungkin menelliti seluruh anggota populasi, Ferdinand (2006). Tahapan selanjutnya adalah menentukan jumlah 
sampel dari populasi yang sudah ada. Penentuan jumlah sampel menggunakan pendekatan statistic (traditional statistic model), didasarkan pada rumus formula statistic pendekatan Yamane (1973) dalam Ferdinand (2006):

$$
n=\frac{N}{1+N d^{2}}
$$

Keterangan:

$\mathrm{n}=$ jumlah sampel

$\mathrm{N}=$ ukuran populasi

$\mathrm{d}=$ margin of error $(10 \%)$

Jumlah populasi adalah 76 orang pegawai, sehingga jumlah sampel yang dihitung berdasarkan rumus Yamane dengan $\mathrm{d}=0.1$ adalah sebesar:

$$
\begin{aligned}
& n=\frac{76}{1+76(0,1)^{2}} \\
& \mathrm{~N}=43.18
\end{aligned}
$$

Dari 76 kuesioner yang disebar, jumlah kuesioner yang kembali dalam waktu sesuai dengan yang direncanakan dan dapat diolah sebanyak 47 kuesioner. Jumlah sampel yang kembali melebihi jumlah sampel minimal. Ferdinand (2006) mengemukakan bahwa semakin besar sampel maka semakin besar kemungkinan untuk membuat pengukuran yang tepat, maka dalam penelitian ini kuesioner yang diolah lebih besar dari sampel yang ditentukan.

Variabel adalah segala sesuatu yang menjadi sasaran penelitian yang menunjukkan variabel penelitian membantu dalam menentukan teknik analisis data (Hadi, 2000). Penelitian ini terdapat satu variabel terkait, yaitu kinerja pegawai dan ada satu variabel bebas, yaitu komunikasi organisasi. Indikator dalam penelitian komunikasi organisasi antara lain: pemahaman, kesenangan, pengaruh pada sikap, hubungan yang semakin baik dan tindakan. Sedangkan untuk indikator kinerja karyawan adalah kualitas kerja, kuantitas kerja, sikap, ketepatan waktu, efektivitas, kemandirian, dan komitmen kerja. Dengan desain penelitian yaitu:

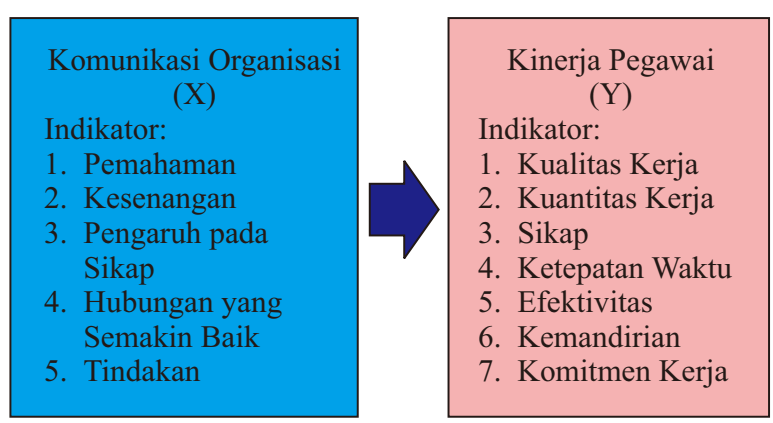

Skala pengukuran dengan menilai hubungan antara variabel penelitian, indikator empiric dan skala pengukuran. Dalam penelitian ini, alat ukur yang digunakan yaitu: variabel komunikasi dan kinerja yang dibuat dalam bentuk skala likert.

Uji validitas adalah perhitungan derajat kesesuaian hasil penelitian dengan keadaan sebenarnya (Suryabrata, 2005). Suatu item dapat dinyatakan valid jika koefisien korelasinya $>0.25$ (Anwar, 1998). Uji validitas ini menggunakan bantuan program SPSS 23.0 for Windows.

\section{HASIL DAN PEMBAHASAN \\ 1. Karakteristik Responden}

Dalam penelitian pengaruh komunikasi organisasi terhadap efektivitas kinerja pegawai PPSDMA Tahun 2018, diketahui bahwa sebagian besar responden berjenis kelamin laki-laki dengan presentasi $74.5 \%$.

Tabel 1. Karakteristik Responden Berdasarkan Jenis Kelamin

\begin{tabular}{|c|c|c|}
\hline Jenis Kelamin & Jumlah & Presentase (\%) \\
\hline Laki-laki & 35 & 74.5 \\
\hline Perempuan & 12 & 25.5 \\
\hline Total & 47 & 100.00 \\
\hline
\end{tabular}

Sumber: olahan data primer, 2018.

Lalu mayoritas berusia 35 - 44 tahun dengan presentase sebesar $48.9 \%$ dengan usia yang masih produktif untuk melaksanakan pekerjaan.

Tabel 2. Karekteristik Responden Berdasarkan Usia

\begin{tabular}{|c|c|c|}
\hline Usia (Tahun) & Jumlah & Persentase \\
\hline$<25$ tahun & 0 & 0.0 \\
$25-34$ tahun & 8 & 17.0 \\
$35-44$ tahun & 23 & 48.9 \\
$>44$ tahun & 16 & 34.0 \\
\hline Total & $\mathbf{4 7}$ & $\mathbf{1 0 0 . 0 0}$ \\
\hline
\end{tabular}

Sumber: olahan data primer, 2018.

Responden berpendidikan S2 dengan presentase 39.1\% dimiliki oleh PPSDMA untuk mendukung kegiatan organisasi mengingat PPSDMA adalah unit yang memiliki tugas dan fungsi sebagai pusat pengembangan sumber daya manusia aparatur KESDM. 
Tabel 3. Karakteristik Responden Berdasarkan Pendidikan Terakhir

\begin{tabular}{|c|c|c|}
\hline $\begin{array}{c}\text { Pendidikan } \\
\text { Terakhir }\end{array}$ & Jumlah & Persentase \\
\hline SMU & 10 & 21.7 \\
D3 & 2 & 4.3 \\
S1 & 16 & 34.8 \\
S2 & 18 & 39.1 \\
\hline Total & $\mathbf{4 7}$ & $\mathbf{1 0 0 . 0}$ \\
\hline
\end{tabular}

Sumber: olahan data primer, 2018.

Responden dengan masa kerja lebih dari 10 tahun dengan presentase $68.1 \%$ sehingga sebagian besar pegawai telah memiliki pengalaman pekerjaan.

Tabel 4. Karakteristik Responden Berdasarkan Masa Kerja

\begin{tabular}{|c|c|c|}
\hline Masa Kerja & Jumlah & Persentase \\
\hline$<1$ tahun & 0 & 0.0 \\
$1-5$ tahun & 8 & 17.0 \\
$6-10$ tahun & 7 & 14.9 \\
$>10$ tahun & 32 & 68.1 \\
\hline Total & $\mathbf{4 7}$ & $\mathbf{1 0 0 . 0}$ \\
\hline
\end{tabular}

Sumber: olahan data primer, 2018.

\section{Karakteristik Variabel Penelitian}

Dilihat pada aspek komunikasi organisasi dengan skor rata-rata sebesar 2.93 dengan standar deviasi0.488 sehingga dapat dikatakan bahwa efektivitas komunikasi organisasi tinggi.

Tabel 5. Hasil Pengukuran Tiap Aspek Komunikasi Organisasi

\begin{tabular}{|l|c|c|c|}
\hline \multicolumn{1}{|c|}{ Aspek } & $\begin{array}{c}\text { Rata- } \\
\text { rata }\end{array}$ & $\begin{array}{c}\text { Standar } \\
\text { Deviasi }\end{array}$ & Kategori \\
\hline Kesenangan & 2.7 & 0.366 & Tinggi \\
\hline Pengaruh pada Sikap & 2.45 & 0.55 & Rendah \\
\hline $\begin{array}{l}\text { Hubungan yang } \\
\text { Semakin Baik }\end{array}$ & 2.9 & 0.533 & Tinggi \\
\hline Tindakan & 3.4 & 0.593 & Tinggi \\
\hline $\begin{array}{l}\text { Komunikasi } \\
\text { Organisasi }\end{array}$ & 2.93 & 0.488 & Tinggi \\
\hline
\end{tabular}

Sumber: olahan data primer, 2018.

Kemudian pada aspek kinerja menunjukkan skor tertinggi pada aspek sikap dan skor terendah pada aspek kualitas kerja dengan skor rata-rata 2.81 yang termasuk bahwa kinerja pegawai tinggi.
Tabel 6. Hasil Pengukuran

Tiap Aspek Kinerja Karyawan

\begin{tabular}{|l|c|c|c|}
\hline \multicolumn{1}{|c|}{ Aspek } & $\begin{array}{c}\text { Rata- } \\
\text { rata }\end{array}$ & $\begin{array}{c}\text { Standar } \\
\text { Deviasi }\end{array}$ & Kategori \\
\hline Kualitas Kerja & 2.3 & 0.9 & Rendah \\
\hline Kuantitas Kerja & 3.2 & 0.6 & Tinggi \\
\hline Sikap & 3.25 & 0.5 & Tinggi \\
\hline Ketepatan Waktu & 2.7 & 0.4 & Tinggi \\
\hline Efektivitas & 2.55 & 0.55 & Tinggi \\
\hline Kemandirian & 2.7 & 0.55 & Tinggi \\
\hline Komitmen Kerja & 3 & 0.46 & Tinggi \\
\hline Kinerja Karyawan & 2.81 & 0.56 & Tinggi \\
\hline
\end{tabular}

Sumber: olahan data primer, 2018.

\section{Efektivitas Komunikasi Organisasi}

Berdasarkan hasil yang yang diperoleh menunjukkan bahwa sebagian besar memberikan skor 46-59 atau dalam kategori efektif, dengan demikian dapat dinyatakan bahwa komunikasi organisasi berjalan efektif.

Tabel 7. Deskripsi Hasil Pengukuran Efektivitas Komunikasi Organisasi

\begin{tabular}{|c|c|c|c|}
\hline Skor & Kategori & $\begin{array}{c}\text { Skala } \\
\text { Likert }\end{array}$ & $\begin{array}{c}\text { Jumlah } \\
\text { Kategori }\end{array}$ \\
\hline $60-72$ & Sangat Efektif & 4 & 11 \\
\hline $46-59$ & Efektif & 3 & 35 \\
\hline $32-45$ & Tidak Efektif & 2 & 1 \\
\hline $18-31$ & $\begin{array}{c}\text { Sangat Tidak } \\
\text { Efektif }\end{array}$ & 1 & 0 \\
\hline
\end{tabular}

Sumber: olahan data primer, 2018.

\section{Efektivitas Kinerja Pegawai}

Berdasarkan hasil yang diperoleh menunjukkan bahwa terdapat 38 responden yang memberikan skor 36-46 atau dalam kategori efektif, dengan demikian dapat dinyatakan bahwa kinerja pegawai efektif.

Tabel 8. Deskripsi Hasil Pengukuran Kinerja Pegawai

\begin{tabular}{|c|c|c|c|}
\hline Skor & Kategori & $\begin{array}{c}\text { Skala } \\
\text { Likert }\end{array}$ & $\begin{array}{c}\text { Jumlah } \\
\text { Kategori }\end{array}$ \\
\hline $47-56$ & Sangat Efektif & 4 & 1 \\
\hline $36-46$ & Efektif & 3 & 38 \\
\hline $25-35$ & Tidak Efektif & 2 & 8 \\
\hline $14-24$ & $\begin{array}{c}\text { Sangat Tidak } \\
\text { Efektif }\end{array}$ & 1 & 0 \\
\hline
\end{tabular}

Sumber: olahan data primer, 2018. 


\section{Pengaruh Komunikasi Organisasi terhadap Kinerja Karyawan}

Ada hubungan yang positif dan signifikan antara variabel $\mathrm{X}$ dan variabel $\mathrm{Y}$. Besarnya hubungan antara dua variabel tersebut adalah 0.641. Demikian halnya jika dilihat dari arah korelasinya menunjukkan arah yang positif, artinya semakin positif komunikasi organisasi maka semakin tinggi pula efektifitas pegawai. Apabila dilihat dari (sumbangan efektif) variabel efektifitas komunikasi organisasi terhadap kinerja pegawai yang dapat dihitung melalui koefisien determinasi $\left(\mathrm{R}^{2}\right)$ yakni sebesar 0.410 (kuadrat dari $0.641)$.

Hal ini berarti besarnya pengaruh variabel komunikasi organisasi terhadap efektifitas kinerja pegawai adalah sebesar $41 \%$, sedangkan sisanya yakni sebesar $59.0 \%$ diterangkan oleh variabel lain yang tidak diteliti.

Tabel 9. Uji Hipotesis

Correlations

\begin{tabular}{|c|c|c|c|}
\hline & & $\begin{array}{c}\text { Komunikasi } \\
\text { organisasi }\end{array}$ & Organisasi \\
\hline \multirow[t]{3}{*}{$\begin{array}{c}\text { Komunikasi } \\
\text { Organisasi }\end{array}$} & $\begin{array}{l}\text { Pearson } \\
\text { Correlation }\end{array}$ & 1 & $.641^{* *}$ \\
\hline & Sig. (2-tailed) & & .010 \\
\hline & $\mathrm{N}$ & 47 & 47 \\
\hline \multirow[t]{3}{*}{$\begin{array}{c}\text { Kinerja } \\
\text { Organisasi }\end{array}$} & $\begin{array}{l}\text { Pearson } \\
\text { Correlation } \\
\end{array}$ & $.641^{* *}$ & 1 \\
\hline & Sig. (2-tailed) & .000 & \\
\hline & $\mathrm{N}$ & 47 & 47 \\
\hline
\end{tabular}

**. Correlation is significant at the 0.01 level (2-tailed). Sumber : Olahan Data Primer, 2018

Dari hasil penelitian yang telah dilakukan di PPSDMA KESDM, terdapat pengaruh positif yang signifikan antara efektivitas komunikasi organisasi dengan efektivitas kinerja pegawai. Argument ini didasarkan oleh sebuah logika bahwa semua pekerjaan di dalam instansi pada kenyataannya saling berhubungan, dan buruknya komunikasi organisasi bidang/bagian di dalam organisasi akan berpengaruh negatif terhadap kinerja pegawai bidang/bagian lain yang tentu saja tujuan dari organisasi tidak akan tercapai.

Hal ini dapat ditunjang dari teori Max Weber tentang birokrasi karena organisasi adalah suatu kerjasama sekelompok orang untuk mencapai tujuan bersama.

Kesimpulan yang dapat diambil adalah tinggi rendahnya efektivitas kinerja pegawai dipengaruhi oleh komunikasi organisasi. Makin efektif komunikasi organisasi dilakukan, maka semakin tinggi pula kinerja pegawai. Hal ini ditunjang oleh pendapat Gibson bahwa ada 3 faktor yang berpengaruh terhadap kinerja 1) faktor individu: kemauan, keterampilan, latar belakang keluarga, pengalaman kerja, tingkat sosial dan demografis seseorang; 2) faktor psikologis: persepsi, peran, sikap, kepribadian, motivasi dan kepuasan kerja; $3)$ faktor organisasi: struktur organisasi, komitmen, desain pekerjaan, kepemimpinan, sistem penghargaan (reward system), yang di dalamnya terdapat komunikasi organisasi (dalam Cokroaminoto, 2007).

Memperbaiki komunikasi organisasi pada institusi berarti memperbaiki kinerja institusi. Argument ini didasarkan oleh sebuah logika semua pekerjaan di dalam institusi pada kenyataannya saling berhubungan. Sebab pada dasarnya bekerja tidak hanya membutuhkan sebuah penghargaan bersifat materi saja akan tetapi bekerja juga membutuhkan interaksi sosial, dengan rekan kerja ataupun atasan yag ramah dan bersahja, dengan suasana komunikasi yang harmonis maka akan menghantarkan seseorang pada kinerja yang baik pula.

\section{PENUTUP}

Kesimpulan dan saran dari penelitian "Pengaruh Komunikasi Organisasi Terhadap Efektivitas Kinerja Pegawai di Pusat Pengembangan Sumber Daya Manusia Aparatur", kesimpulan yang diambil adalah bahwa komunikasi organisasi memiliki pengaruh terhadap efektivitas kinerja pegawai di PPSDMA, namun dari hasil pengukuran tiap aspek kinerja pegawai, aspek nilai yang paling rendah adalah aspek kualitas kerja.

Saran yang peneliti ingin sampaikan bagi para pimpinan dan seluruh pegawai hendaknya melatih keterampilan komunikasi terutama komunikasi antarpersonal agar tercipta kesepahaman sehingga dapat meningkatkan kualitas dari hasil kerja. Pimpinan hendaknya membagi informasi yang dibutuhkan pegawai dan memberikan bimibingan juga membuat perencanaan untuk memproyeksikan kesempatan dan hambatan sehingga dapat menyelasaikan pokok persoalan yang penting secara cepat, karena pimpinan dikatakan berhasil bila pegawai dan teamwok nya juga berhasil mencapai tujuan organisasi.

Untuk para pegawai, hendaknya meningkatkankinerjanya sebagai bentuk tanggungjawab profesinya demi tercapainya tujuan sebuah organisasi, yakni meningkatkan kualitas dan kuantitas serta membangun Brand yang lebih baik untuk organisasi demi kelancaran, kemudahan, 
kenyamanan dalam bekerja maka dibutuhkan adanya komunikasi yang baik, karena pada dasarnya individu akan merasa nyaman bekerja bila mempunyai hubungan harmonis antar rekan maupun pimpinan yang bisa menjadi motivasi tersendari bagi pegawai, sehingga kinerjapun bisa lebih ditingkatkan.

\section{Daftar Pustaka}

Kristantono, R. (2008).Teknik Praktis Riset Komunikasi. Jakarta: Penerbit Kencana Prenada Media Group.

Masmuh, A. (2010). Komunikasi Organisasi dalam Perspektif Teori dan Praktik. Malang: Penerbit UMM Press.

Miftah, E. (2010). Arti Kinerja. Jakarta: Penerbit AKN VBPK RI.

Priyatno, D. (2010). Teknik Mudah dan Cepat Melakukan Analisis Data penelitian dengan SPSS. Yogyakarta: Penerbit Gava Media.

Sadarmayanti, \& Syarifudin Hidayat. (2011). Metodologi Penelitian. Bandung: Penerbit Mandar Maju.
Suprapto. (2011). Pengantar Ilmu Komunikasi dan Peran Manajemen dalam Komunikasi. Yogyakarta: Penerbit CAPS.

Effendy, Onong Uchjana. (2013). Ilmu, teori dan Filsafat Komunikasi. Bandung: Penerbit Citra Aditya Bakti.

Deddy Mulyadi. (2015). Perilaku Organisasi dan Kepemimpinan Pelayanan. Bandung: Penerbit Alfabeta.

Wayne Pace, R, \& Don F. Faules. (2015). Komunikasi Organisasi. Bandung: Penerbit Remaja Rosdakarya.

Wirawan. (2015). Evaluasi Kinerja Sumber Daya Manusia: Teori, Aplikasi dan Penelitian. Jakarta: Penerbit Salemba Empat.

Irham Fahmi. (2016). Perilaku Organisasi, Teori, Aplikasi dan Kasus. Bandung: Penerbit Alfabeta.

Ghozali, I. (2016). Aplikasi Analisis Multivariate dengan Program IBM SPSS 23. Semarang: Penerbit Universitas Diponegoro. 